\title{
"TREATY PRINCIPLES": CONSTITUTIONAL RELATIONS INSIDE A CONSERVATIVE JURISPRUDENCE
}

\author{
PG McHugh ${ }^{*}$
}

\begin{abstract}
This article looks at the impact and afterlife of the groundbreaking Maori Council judgments handed down in the late 1980s by the Court of Appeal presided by the late Sir Robin Cooke (as he then was). This article refutes any notion of constitutional relations with Māori being founded on race despite unilateral (and long discarded) legal design tending towards that characterisation. The true pattern has been iwi-based and it has arisen from the continuity of whakapapa in the organization of Maori political life and relations with the state notwithstanding meddlesome but ultimately ineffectual legislative attempts to dilute tribalism. Over the past twenty plus years, the Treaty claims processes initiated in 1985 have accentuated and revitalised that tribalism. Far from licensing judicial interventionism "Treaty principles" are part of an embedded and conservative jurisprudence of Māori affairs. Their elimination from legislation would amputate a major segment of that jurisprudence. The courts, whose profile in this broad field (Treaty claims processes most notably) is mostly a resiling one, would respond by generating their own version. The legacy of Sir Robin Cooke's court is deep-rooted and thoroughly integrated into the New Zealand legal system.
\end{abstract}

In early September 2006, as I was preparing the earliest version of this paper for a public lecture at Victoria University of Wellington, there came the sad news of the death of Lord Cooke of Thorndon. For me Robin's personal support was considerable, particularly when I was a young scholar then junior academic at Cambridge University ${ }^{1}$ during the 1980 s working in what was then the uncharted territory of common-law aboriginal rights. I opened my lecture with a tribute to him as a jurist, scholar and friend and have since revised this text to emphasise more closely our personal connection, which was especially strong during the key period when he was adjudicating upon important issues surrounding Māori claims.

* Reader in Law at the University of Cambridge and Ashley McHugh Ngai Tahu Professor of Law at Victoria University of Wellington

1 This is a debt I have recorded elsewhere, see "Aboriginal Title in New Zealand: A Retrospect and Prospect" (2004) 2 NZJPIL 139. 
In the early 1980s the field of aboriginal rights was still primarily an academic endeavour in which a small group of common law scholars, mostly Canadian, exhorted national courts to embark upon the process of articulating a set of rights, especially in relation to customary property. As it was, Robin never sat on a court that adjudicated directly in this field although he and the bench of the Court of Appeal over which he presided issued highly sympathetic dicta. Once, long after the chance had disappeared, he confessed to me privately his disappointment that the Crown had not appealed Williamson J's judgment in Te Weehi v Regional Fisheries Officer. ${ }^{2}$ One sensed he wanted to strengthen this first and first-instance recognition of common law aboriginal title by a New Zealand court. One sensed also, although Robin - always the embodiment of judicial propriety towards the executive branch - never commented directly to me on this point, that the Government had not wanted to give his Court that opportunity. Nonetheless he grasped the underlying concern of that early-1980s aboriginal-rights scholarship. Essentially, it was an argument for correction of what was a surviving historical feature of the Anglo-settler jurisdictions of Canada and Australasia, namely the omission of tribal peoples from the juridical compass of common-law constitutionalism. The admission of tribal peoples into that legitimating rights-place was a process, the scholarship argued, where the initial onus was on the courts. The governing principle of non-justiciability had for decades given politicians a free hand in the state's management of relations with tribal peoples, so the political branch had no interest in sponsoring revision of the legal position. It was for the courts to act, to legitimise the position of tribal peoples at a time when increasing militancy threatened taking it in another direction. This was the thrust of the scholarship: Even at that stage it had the inherently conservative design of incorporating tribes into mainstream legalism. ${ }^{3}$

During the late 1980s, the New Zealand Court of Appeal addressed that history in the remarkable sequence of Maori Council cases presided over by Sir Robin (as he then was). These were cases that shifted the constitutional tectonic plates irreversibly, making impossible a return to the old pattern of juridical exclusion. The core notion was one of admitting the justiciability of the relationship between the Crown and Māori. That was a form of legal revisionism accepted as

2 Te Weehi v Regional Fisheries Officer [1986] 1 NZLR 682 (HC).

3 In the New Zealand context the conservative aspect of common-law aboriginal rights argumentation was recognised and criticised by radical academic commentators such as Moana Jackson, DV Williams and Jane Kelsey. See RA Sharp Justice and the Maori: The Philosophy and Practice of Maori Claims in New Zealand since the 1970s (2 ed, Oxford University Press, Auckland, 1997) and Paul Havemann "The Pakeha Constitutional Revolution: Five Perspectives on Maori Rights and Pakeha Duties" (1993) 1 Waikato LR 53 for a history and analysis of this scholarship. Equally, conservative commentators (practitioners mostly, such as EJ Haughey and G Chapman, of a markedly un-academic character) criticised the "creativity" of this scholarship. Certainly when the key judgments issued in the four key common-law jurisdictions of Canada (1973), United States (1978), New Zealand (1987-91) and Australia (1992) accusations of "judicial activism" were rife, particularly by members of the political branch. There is no doubt but that admission to the rights-discourse, by which aboriginal groups have been encircled in the past twenty years, was initiated by the courts: see PG McHugh Aboriginal Societies and the Common Law: A History of Sovereignty, Status and Self-Determination (Oxford University Press, Oxford, 2004). 
commonplace now, and a step that retrospect shows as eventually carrying an inherent conservatism, a quality on which I comment more fully below. Further, in the late 1980s the step was consistent with the widening reach of public law at large, a trend suggesting that it would have been more remarkable had the Court of Appeal not brought Māori into the rights-place. Nonetheless at the time the Maori Council cases were seen, rightly, as a breathtaking and paradigm-changing leap from which there could be no turning back. All the obituarists have rightly noted Robin's leadership in that important step, seeing it as one of his greatest, if not his greatest, contribution to New Zealand jurisprudence and politics in the last quarter of the twentieth century. Historical contextualisation does not diminish so much as underline its significance.

This article is concerned with that constitutional space and the shape that it has taken in the twenty years since the Maori Council cases. In my September 2006 address, I looked at that modern history of Māori constitutional presence in the light of the Principles of the Treaty of Waitangi Deletion Bill then before Parliament. ${ }^{4}$ It was known then that this Bill had no legs and would not even have made it onto the floor of the House were it not for the coalition agreement. By the time this article is published it will have become a very minor and passing footnote in the history of the Treaty jurisprudence. However, even as a fleeting minnow, the Bill raised questions about the way in which the New Zealand constitutional system has accommodated Māori in the past twenty years, in particular their claims associated with the Treaty of Waitangi. The death of Robin gave another more poignant reason to review that history, especially in the light of the agenda-setting contribution of his Court of Appeal in the sequence of Maori Council cases (1987-91). ${ }^{5}$ In these cases the Court endorsed the Waitangi Tribunal's articulation of the range of "Treaty principles" as set out in key statutory regimes, particularly those establishing the Tribunal's jurisdiction to hear historical claims (1985) and the corporatising of state assets (1986). It is this process of judicial interpretation and application of Treaty principles that the 2006 Bill sought to abort. Other events before and after those of mid-2006 have also motivated this article, in particular the Orewa speech in February 2004 of Don Brash, as Leader of the Opposition. This cynical speech was a worrying and incendiary mischaracterisation of the constitutional position of Maori as being based on "race".

4 This Member's Bill was introduced by R Doug Woolerton MP, New Zealand First on 29 June 2006. The Bill failed its second reading on 7 November 2007 by a vote of 112 to 7 .

5 New Zealand Maori Council v Attorney-General [1987] 1 NZLR 641 (CA); Tainui Maori Trust Board v Attorney-General [1989] 2 NZLR 513 (CA); Te Runanga o Muriwhenua Inc v Attorney-General [1990] 2 NZLR 641. In his Harkness Henry Lecture "The Challenge of Treaty of Waitangi Jurisprudence" (Hamilton, 1994), Sir Robin noted (at note 27):

The first Muriwhenua judgment also led to an exchange rather out of the ordinary. In her Waitangi Day speech in 1990 Her Majesty the Queen had quoted some words from the first Maori Council case about partnership and the utmost good faith. She built on these words in a way referred to in the Muriwhenua judgment [ibid, 655], and there was some consequent correspondence. 
To my mind those events necessitate refreshment of our awareness of the modern and complex jurisprudence of Māori affairs in the rights era launched by Sir Robin Cooke's Court. What is the juridical foundation of the Māori jurisprudence, and how and where has that been articulated inside New Zealand's constitutional sphere in the years since the Maori Council cases? That legalism of the past twenty years will be termed the "Māori jurisprudence", meaning the body of law and practice inside the constitutional system of New Zealand that affects Māori affairs and that in various ways incorporates elements of tikanga Māori into that system. It will be argued that "Treaty principles" form a part of that wider jurisprudence, an important one to be sure, but they are far from its entirety. It will be further argued that since the foundational Maori Council cases, that jurisprudence has developed in a cautious and conservative manner. Repealing "Treaty principles" from the various statutory regimes would create a legal vacuum inviting the judicial "activism" 6 the 2006 Bill holds in scorn.

The explanatory note declared that the Principles of the Treaty of Waitangi Deletion Bill 2006 (Treaty Principles Deletion Bill) sought "to correct an anomaly that has harmed race relations in New Zealand since 1986 when the vague term 'the principles of the Treaty of Waitangi' was included in legislation." ${ }^{7}$ Māori, the note insisted, had not sought the legislation (a protestation that seems to indicate forgetfulness of the Waitangi Tribunal's role in securing the belated inclusion of what became section 9 of the State-Owned Enterprises Act 1986). ${ }^{8}$ Rather, it had been inserted by the "paternalistic and interfering Ministers" of the Fourth Labour Government. That vagueness, the note further complained, had been aggravated by the interpretation of the phrase in the courts. They had taken "an increasingly activist, liberal and broad licence" in the interpretation of it and, yet, "despite nearly two decades of existence, these principles remain largely undefined and ambiguous." This vagueness, the note continued, had benefited the legal profession but there had been "no tangible benefit for Maori". Rather it diverted money from them and also it had "surreptitiously created unrealistic expectations among Maori in relation to their entitlements from society." Treaty principles "allowed some Maori to portray themselves as victims constantly in grievance mode" and they had become "a divisive mechanism which has set one group of New Zealanders against one another." The note ends by suggesting that Treaty principles were taking New Zealand "down a destructive path of separate development" towards the apartheid associated with South Africa, a

6 This is a term often used by my legal colleagues, academic and professional, invariably in a negative sense to criticise a style of judgment they regard as too overtly manipulative, and contrived towards engineering legal change beyond the reasonable compass of the case law. It is a term with which I have great personal discomfort and one that Sir Robin in conversation with me once dismissed as meaningless.

7 Principles of the Treaty of Waitangi Deletion Bill 2006, no 66-1 (Explanatory Note).

8 Sir Robin Cooke made this point in his Harkness Henry lecture), above n 5, text accompanying note 16: "Section 9 was inserted in the legislation in response to representations made to the government by the Tribunal and Maori leaders." 
country "the world watched with horror." This, the note implied chillingly, was where the history of race-based treatment would lead us.

Strong and fearful stuff, but look at its suppositions a little more closely. The explanatory note spoke of "Maori" and "society" and damage to this country's race relations through the increasingly activist application of Treaty principles by the courts. One looks then to the Treaty of Waitangi and finds that it is not a treaty between "Maori" and "society" but between certain representatives chiefs - of political formations described as tribes ${ }^{9}$ and Her Majesty Queen Victoria (though not, interestingly, "her heirs and successors"). The Bill's explanatory note treated Māori monolithically as a race, a single all-encompassing racial entity, yet where is the treaty with the Māori "race"? Dealing with people on the basis of race is divisive, the note protested, but one sees nothing in the Treaty insisting that Maori be given preferential treatment as a race. It must, then, be said at the outset and emphatically: race has nothing to do with the Treaty of Waitangi or the principles accredited to it. Why, one asks, does an MP or any politician want to characterise as an issue of race a constitutional document that does not purport to be founded on that basis? Nicky Hager's recent book The Hollow $\mathrm{Men}^{10}$ gives a worrying answer: it panders to the white electorate's racism and prejudice, securing electoral gain for those who play the "race card".

We are rightly wary of those who play the "race card" but rarely embark upon a deeper enquiry into why it is so objectionable. The first part of this article is an examination from the legal and constitutional perspective. I want to issue a reminder why, from that perspective, Māori claims under the Treaty of Waitangi are not a matter of race. And I want to do this by looking closer at this notion of race as the juridical means of situating the Māori jurisprudence. The explanatory note forebodingly reminded us where the history of race-based treatment could lead. Well, indeed; but it seems the author of the Bill needed a pointed reminder more than the public he patronised so selfrighteously (and pompously). The second part of this lecture will look at the role of Treaty principles inside the broader more complex Māori jurisprudence, for they are far from forming the whole or even the juridical axis of that jurisprudence. That jurisprudence and the Treaty principles sector of it I will characterise as deeply conservative and embedded inside the public sphere, and mostly as lying well below the public sightline. I argue that the removal of the Treaty principles segment of that complex legalism would produce a vacuum that the courts would feel obliged to replace. Treaty principles have not been generating an increasing judicial activism, as the Bill's note

9 The actual phrase in the English version is "The Chiefs of the Confederation of the United Tribes of New Zealand and the separate and independent Chiefs who have not become members of the Confederation". I am using the term compendiously to include iwi and hapū. I am aware of the intense debate about the relation of these inside Māori culture, and the histories of that relation (which are highly regionalised); however for present purposes I use the term "tribe" to embrace both organic whakapapa (genealogically associated) forms of customary political organisation.

10 Nicky Hager The Hollow Men: A Study in the Politics of Deception (Craig Potton Publishing, Nelson, 2006) $79,89$. 
claims, but rather they have allowed courts to take what is presently a resiling profile. The dramatic exception to that - the Court of Appeal judgments in the foreshore and seabed case - was, of course, not a Treaty principles case but rested on common law principles, that is to say matters of statutory interpretation and aboriginal title to which the Treaty was at most peripheral.

In short, this article argues that Treaty principles are not about "race" (the catch-cry of the mischievous and constitutionally uninformed). Anyway, those principles are only a portion of the Māori jurisprudence. They represent a deeply conservative portion the removal of which would excite rather than extirpate judicial "activism".

\section{I "IT'S NOT ABOUT RACE": THE RISE OF RACIALISED THOUGHT AND ITS ABSORPTION INTO ANGLO-SETTLER LEGALISM}

Before the nineteenth century the diversity of human societies was not founded in a notion of race such as developed from that time. Until the early nineteenth century mankind was seen as one large family and by this monogenic view the differences from society to society were seen as grounded in environment, education and divine order. One can see this in the usual manner of reference to Indian tribes on the American continent throughout the seventeenth and eighteen centuries. Most usually they were "savage" and "barbarous", defined by the perception of their qualities rather than by the colour of their skin. However in the early nineteenth century some came to see mankind as composed of many families or species, this being known as polygenism. Although the debate between the two approaches was made obsolete by the rise of Darwinism, the emergence of a discourse counter to the established one of monogenism contributed to the establishment, institutionalisation, and authority of science. It has been said that polygenism ultimately served three interconnected functions that made it attractive to those who deployed it and which made it an extension of the Enlightenment project. First it repudiated the biblical chronology of Creation. Although that had been the subject of long dispute, the polygenetic theorists based their critique upon the evidence from anthropology, philology, and archaeology. The discrediting of the biblical chronology both contributed to, and resulted from, a second aspect of the polygenic theory: the emphasis upon the principle of "free inquiry" and the divorce of religious from scientific/philosophical knowledge. However, that "free inquiry" did not just involve the essentially secular pursuit or production of knowledge for its own sake. Its third aspect lay in accentuating how scientific knowledge had come into being with the Enlightenment in order to "better" the individual and society. Scientific knowledge was to be a bio-social discursive formation that could be widely deployed to analyse and resolve even the most intractable social problems. ${ }^{11}$

11 This paragraph's account of these three aspects of polygenism is taken from Ricardo Brown "Human Variety, the Species Question, and the Origins of Race" (Paper to the Science and Race in $19^{\text {th }}$ Century America Panel, American Studies Association Annual Meeting, 11 November 2004). 
That scientificism had, of course, a legal form in late-nineteenth century legal positivism and the industrialisation of law in the profession and professoriate. Not only did law become a forensic science in which the command located in statute or case was clinically extracted by trained practitioners, but that process became the closed shop of that clerisy by way of an organised and disciplined profession and formal classroom instruction in the universities. And in the secularising world it generated the attendant belief (one that still endures in legal thought long after positivism's grip has weakened) that law could be used instrumentally to effect social change. Law became a manifestation of an inherently dynamic and purposive (as well as purely) human agency. ${ }^{12}$

Legal positivism was far from the only (and belated at that) intellectual product of nineteenth century scientificism. Mid-century there also emerged the notion of "scientific racialism". Historians of thought have tended rather simplistically to depict that emergent discursive practice as entailing a change from environmental to biological determinism, ${ }^{13}$ but the point is that it encouraged an approach towards cultural difference that enabled it to be characterised primarily by physical appearance. There was, so to speak, a biologising of difference. Arthur de Gobineau's An Essay on the Inequality of the Human Races (1853) is often regarded as one of the earliest and most influential examples of the new scientific racialism. Gobineau saw the decay of race and the mixing of blood (miscegenation) as the cause of the fall of civilisations. He distinguished between the white, the black, and the yellow in terms of the relative limitations of reason, thought, and intellect in non-white races and the predominance of energy, desire, and intensity, combined paradoxically with passivity, to be found in the black and yellow races. ${ }^{14}$

But this was not simply the discourse of intellectuals. Enough of that emergent ideology of race passed into the muddy mainstream of popular thought where its secularising tendency was diluted and where it shored up Anglo-American expansionism. In America, scientific racialism, in its corrupt populist form, helped to nourish the notion of Manifest Destiny (the term first used in 1845 to describe the rightful destiny of the United States to extend across the continent). ${ }^{15}$ The emergent idea of race as a biological difference helped justify the forced removal of the Cherokee west of the Mississippi River (1832) and the continuance of the institution of slavery in the antebellum

12 Roger Cotterell The Politics of Jurisprudence: A Critical Introduction to Legal Philosophy (Butterworths, London, 1989) 80 .

13 See Bruce Dain "Was There a Transition to Modern Racism in the Ante-bellum Era?" (Paper to the Science and Race in $19^{\text {th }}$ Century America Panel, American Studies Association Annual Meeting, 11 November 2004). See also Mark Francis "The "Civilizing" of Indigenous People in Nineteenth-Century Canada" (1998) 9 Journal of World History 51.

14 Zohreh T Sullivan "Race, Gender and Imperial Ideology in the Nineteenth Century" (1989) 19 NineteenthCentury Contexts 19.

15 "[I]t would be the systematic body of concepts and beliefs that powered American life and American culture." Michael T Lubragge Manifest Destiny (Department of Alfa-informatica, University of Groningen, Groningen, 1997). 
American republic. Racialism was linked to American expansionism, both physically in the drive westward and economically on the sweaty, whipped brow of slavery. Even though the abolitionists on both sides of the Atlantic prevailed in the mid-nineteenth century there had been implanted into popular consciousness a sense of other societies as inherently different, rather than as being ultimately similar (if, perhaps, unbelieving). The notion of race received an extra boost from the percolation into populist discourse of elements of social Darwinism, derived from the work of Herbert Spencer. In Britain this process gained momentum from two key events - the Sepoy Rebellion (Indian Mutiny) of 1857 and the Morant Bay Rebellion of $1865 .{ }^{16}$ Race and empire, two highly fluid and elusive notions and the more readily put into circulation because of that, slippery grip on popular excitability seemed bound together (for all the anti-imperialism of Spencer himself). At this stage it has been argued the British notion of empire acquired a global character, as a kind of mission to bring and ensure global order and the ascendancy of western civilisation. ${ }^{17}$ Spencer's thought was corrupted into a debased and highly vulgarised popular form depicting cultures as locked unavoidably in competition in which the fittest would survive and flourish. Of course, the evident superiority of the Anglo-European culture (from whence that conceptualising derived) meant that its ascendancy was the outcome of those natural forces of social evolution. The best fate for subject races, indigenous peoples included, was for them to assimilate into the society of the superior European race.

By the late-nineteenth century the notion of race had truly arrived and passed messily into the mainstream. It was, one must stress, a way of seeing and classifying the world that had its origins in nineteenth-century scientificism as absorbed into and mulched by the jumble of other strains of thought that swirled about popular Anglo-American culture of the time. Race has never been the discourse of indigenous peoples. It was and remains an entirely western mode of classifying the Other (hence the arrogance implicit in the Treaty Principles Deletion Bill 2006). And for indigenous peoples there were important consequences stemming from the dominance it had in the white mind's monolithic conceptualisation of them: race allowed the white settler-state to be self-righteously expansionist (meaning it justified their acquisitive attitude towards tribal land). Since race was biological and essentialist, interbreeding was frowned upon and its progeny, the mixed blood or "half-castes" as they were called, became regarded as problematic and a distinct juridical being. Race was assimilationist - it demanded that the non-European (male) citizen should be bleached into a property-owning individual each solely responsible for their own secular salvation. It was also reductionist, allowing settler authorities to shun and deliberately undermine the messy realities of

16 See Karuna Marena "The Crisis of Liberal Imperialism" in Duncan Bell (ed) Victorian Vision of Global Order: Empire and International Relations in Nineteenth-Century Political Thought (Cambridge University Press, Cambridge, 2007) 113-135.

17 Duncan Bell "Victorian Visions of Global Order: An Introduction" in ibid, 1-25. 
tribal political organisation by subsuming the tribes en masse into the much easier sweeping category of race.

And as Anglo-American thought had also reached a view of its law as instrumental - that is to say, law as an instrument for social and cultural change - the settler-state put in place laws that reflected those consequences of its own racialising vision of tribal peoples. By the late-nineteenth century the settler-states of North America and Australasia were actively constructing legal regimes for aboriginal peoples founded upon the racial paradigm their own thought had devised. Laws were used aggressively to acquire the tribes' land by purchase, cession, confiscation or individualisation (the expansionist consequence). Law determined who was indigenous or not based on the scientific measure of blood percentage (the biological and essentialist). Mixed-blood people, many ethnically identifying as aboriginal, were cordoned into a special twilight category, often leaving them neither legally aboriginal nor a full white citizen. Law set in place mechanisms for the transformation of the tribal individual into the secular redemption of enfranchised property-owning citizenship (the assimilationist). Native affairs were treated by the Anglo-settler state as a matter of race, not a series of relations and engagements with various tribal polities (the reductionist). The web of laws passed by settler-states of North America and Australasia thus saw tribalism not as a political manifestation of group coherence, but as a racial attribute or biological propensity of the individual and out of which each tribe member had to be coaxed, coached or perhaps even coerced (as in the residential schools policies of Canada and Australia).

Those legal manifestations of the consequences of racialised thought emerged at a time when the physical suppression of the tribes was well in train in the Great Land Rush of the late-nineteenth century. The Plains Wars, Maori Wars and Métis Rebellion in the second half of the nineteenth century established not only the military ascendancy of the settler-state but licensed its own racebased intellectualisation of that hard-won superiority. If before that time tribes had been seen as distinct political formations each meriting distinct and particular treatment informed by their history of relations with the white government, by the end of that century it was tribalism that was seen as the undesirable attribute. Tribalism rather than tribes had become the issue. By re-conceiving the tribes in a racial manner, the "native problem" could be dealt with on a monolithic basis overlooking the peculiarities of particular groups. In America, for example, that re-conceptualisation allowed a mixture of culturally wide-apart peoples to be removed and crammed together onto reservations, often (as with the Five Civilized Tribes of present-day Oklahoma and the influx onto their land of black freedmen after the Civil War), where they were left to resolve their incompatibilities. In Canada First Nations were dispersed into statutory bands under the federal Indian Act 1876 where race - Indian status under the Act - rather than nationhood defined their being. At least as initially imposed on First Nations, the "band" was a unit of administrative convenience, not a natural political grouping. In Australia the series of aborigines' protection laws passed by each colony and (after federation) state were founded entirely on a racial basis. In these common-law jurisdictions race was literally the governing paradigm. 
Race provided a tidy monolithic way of seeing the tribal societies, a totalising way that dispensed with the messy plurality of tribal nations. For white law-makers it addressed the barrier to the aboriginal individual's advancement towards civilisation arising from the attribute of tribalism. Reservations were established in the United States and Canada overseen by government pharaohs with total control, in the former by the government's arrogation of power from the tribes themselves (and later under the boilerplate constitutions of the Indian Reorganization Act 1934) and in the latter under the federal Indian Act 1876. In these jurisdictions laws of status were applied and registers of membership kept by bureaucrats, many of those in the United States using blood percentages, to determine who was or was not legally an aboriginal. In Australia protectors were appointed with intrusive and far-reaching authority over those Aborigines hapless enough to come under their reach (although many, wisely, stayed away).

New Zealand also moved towards race-based law-making, as embodied in the official policy of assimilation. The native land legislation was justified by the policy of transforming the tribal member into a property-owning individual outside the sphere of the customary. Individualisation of customary title had de-tribalisation as its philosophical goal (even if access to Maori land was its more pragmatic and pressing design).

As a way of perceiving tribal societies and informing the character of laws passed to manage their affairs and assets, the notion of race has, therefore, had a dramatic impact upon them. Yet, it must be stressed that this was not an aboriginal way of seeing the world but a form of monolithic classification that enabled Anglo-American settler polities to construct their own simplified (and simplistic) view of the tribal. Inside those laws the tribal polities continued and adapted: simply because the law of Leviathan sought to dissolve the tribes or replace them with temporary, transitional and westernised vehicles of collective action did not mean that a bleaching result occurred. And certainly aboriginal cultures absorbed some of the race-based legalism surrounding them. ${ }^{18}$ They had considerable agency inside those legal frameworks, such as (in New Zealand) in their dealings with the Native Land Court. Tribes were not passive in their experience and management of race-based legalism. ${ }^{19}$ In all jurisdictions each group has had a history of adaptation

18 One notable North American example was the adoption by Plains tribal nations of rules excluding from tribal membership (and hence access to tribal land) female band members marrying non-Indians. This rule appeared in the late nineteenth century as the Plains wars were depleting young Indian males and white settlers were taking Indian wives in order to obtain land. Often these white husbands wanted to partition their land off from the tribe and were highly resistant to tribal authority. In the late-twentieth century Indian females argued that this loss of status was discriminatory, especially when the marriage had broken down and they were self-identifying tribe members. The authority of the Native American tribe to make this membership rule was upheld by the Supreme Court in Santa Clara Pueblo v Martinez (1978) 436 US 49 however, Canada, prompted by the Human Rights Committee of the United Nations, eventually took the opposite position: see McHugh Aboriginal Societies and the Common Law, above n 3, 248-50.

19 This dynamic interplay of Pākehā legalism and Māori custom is caught by Richard Boast in his book Buying the Land, Selling the Land: Governments and Maori land in the North Island 1865-1921 (Victoria 
and survival and, indeed, absorption of the racialised way of thinking used to corral and re-colourate them.

Yet, having constructed the discourse of race the same settler-state that had contrived and applied it later decided that it would be best to dismantle it, or to put in place mechanisms and laws that tried to overlook it. This was substantially the outcome of the Second World War where the horrific consequences of state-sponsored racialism were all too plain. In the years after the war, Anglo-American jurisdictions decided that the differential treatment of citizens on grounds of race could not be tolerated in a liberal democracy. All common-law jurisdictions moved towards the dismantling of the remnant laws that had the effect of protecting or maintaining the distinctive status of tribal peoples and their land tenure. In America there began the policy of "terminating" federal recognition of tribes, a policy of the 1950s and 1960s; Canada tabled an aptly named White Paper (in 1969) proposing abolition of Indian status and the dissolution of reservations; in Australia the 1967 "citizenship" referendum was seen as a step towards a more aggressive nationally-based approach to Aboriginal assimilation; ${ }^{20}$ and in New Zealand the National Government passed the controversial Maori Affairs Amendment Act 1967 which removed a substantial amount of the protection of Māori freehold land from alienation.

At the same time as proposing the removal of special aboriginal status at law, the North American and Australasian jurisdictions were developing their municipal norms of nondiscrimination. Yet, by trying to declare the legal irrelevance of race and prohibit it as a ground for treatment in the public sphere, the anti-discrimination measures essentially maintained a race-based juridical discourse. If anything the United Nations human rights covenants of 1969 encouraged that persistence in specifying the rights of national minorities in terms of non-discrimination. To the extent then that indigenous peoples were being seen in the 1970 s as rights-bearing groups, it occurred mostly through those emergent human rights norms and implicitly as the right not to be discriminated against on grounds of race. Race remained the governing paradigm. Hence, for example, one finds the passage of the Racial Discrimination Act 1975 in Australia, a crucial Commonwealth statute that remains vital in protecting Aboriginal clan nations from marauding state legislation (concerning native title especially). Similar civil rights legislation strengthening the nondiscrimination norm in areas such as employment and the provision of public services was also passed in the United States and Canada in this period running from the late 1960s through the mid-

University Press, Wellington, 2008). I have read the manuscript of this important and fascinating book which captures law as a site of contest, adaptation, co-option as well as oppression. This is the first major work pioneering and setting the benchmark for a modern tradition of New Zealand legal history, connecting events in New Zealand to international scholarship on the impact of legal imperialism (such as the approach explained by John Comaroff "Colonialism, Culture, and the Law: A Foreword" (2001) 26 Law and Social Inquiry 305$)$.

20 McHugh Aboriginal Societies and the Common Law, above n 3, 337-340. The 1967 referendum leading to the Commonwealth assuming legislative jurisdiction over Aboriginal affairs is discussed more fully below. 
1970s. In New Zealand the important statutes were the Race Relations Act 1971 and the Human Rights Commission Act 1977.

But for indigenous peoples it can be seen, in retrospect, that the theme of this 1970s legalism, though admittedly important, was still only a partial one that did not specifically authorise and endorse their indigeneity which retained at its heart their customary political organisation as tribes. Race was still the core juridical theme. It was not until the mid-1980s that the international and national human rights norms started to reconfigure in a more proactive and sympathetic manner organised around the notion of indigeneity and recognition of the tribe. ${ }^{21}$

\section{CROWN RELATIONS WITH MAORI: THE INVISIBLE TRIBE}

I emphasised earlier that the constitutional basis of the Crown's relations with Māori is not and has never been founded on race. However the historical account just given shows that from the latenineteenth century, when law became a prominent device for the management of aboriginal relations, those laws were being everywhere framed in terms of race. But, as I have stressed, those terms were not those of the tribal societies themselves, nor the conceptualisation made in the terminology of the Treaty of Waitangi, but the projection of a settler-state discourse of cultural difference and domination. One might ask when or how did the common-law systems - specifically, New Zealand - move out of a racially-oriented view of aboriginal relations to a tribalised one, more in step with the way in which those people viewed themselves?

As I have stressed the Treaty of Waitangi was not a treaty between a race and a monarch. It was a treaty between a group of tribal political formations represented through their customary leaders with another formation, an imperial one represented by and through its young Queen. As we know, this Treaty represented certain understandings reached between those customary leaders and the representatives of the imperial Crown about the basis for their co-habitation on the New Zealand islands. The Crown, in exercise of its kawanatanga, established courts and proclaimed the paramountcy of its legal system as a means for the peaceful resolution of disputes. Early on and indeed ever since, Māori sought to use those courts to vindicate the chiefs' understandings of their relations with the Crown. Their recourse to law and the mana of the courts invoked not just the arrangement made on the coastal promontory at Waitangi, but the succession of treaties and arrangements that followed, many (but not all) of them involving their relinquishment of land to facilitate white settlement. These regionalised and localised relations between Crown and tribe constitute the other layer of Treaty relations that the claims process has been revealing. As Richard

21 See generally James Anaya Indigenous Peoples in International Law (2 ed, Oxford University Press, Oxford, 2004) stressing the impact of the United Nations institutions and human rights instruments from the mid-1980s in formulating norms specifically oriented around indigenous peoples. 
Boast has pointed out in an important article they signify an unexplored multi-textual dimension of our constitutional history. ${ }^{22}$

However, the courts established by the Crown for all its subjects were notoriously unreceptive to claims made by representatives of the tribes. Doubtless that unresponsiveness can be explained in terms of the state of legal art of the late-nineteenth to mid-twentieth century, particularly the difficulties with impleading the Crown, absence of the modern-style representative action, and the phantom (that is to say, the non-) personality of the tribe being compounded by the broader racialising view of Crown-Māori relations. Still the courts made it plain that they were closed to the chiefs as a means of protecting tribal interests, to customary land especially, and for supervising their relations with the Crown. Neither the guarantees in the Treaty nor the particular promises in the myriad of land and other deals between Crown and chief could be enforced through the courts. Judges closed the courtroom door by denying the tribes any inherent status as entities inside the legal system to which group rights might attach: English law has always had a stringent and rather narrow view of personality, and its kiwi manifestation was in no mood to let an amorphous custombased group like a tribe into such a zone. And certainly the Māori tribes held no residual and subordinate sovereignty of the type recognised by the American courts. Further, the courts insisted that any rights associated with the Treaty of Waitangi or contained in some pact between Crown and chief required some positive statutory recognition. Only on that basis and to that extent might tribal rights gain recognition inside the legal system.

Yet, by the time that New Zealand courts took that position authoritatively in Parata v Bishop of Wellington $^{23}$ the reality of New Zealand politics had been and continued thereafter to be a highly tribalised one. That is, the Crown had conducted its relations with Maori on the basis of its tribal organisation. The Treaty of Waitangi was the most dramatic expression of that pattern of relations and has dominated most historical surveys of Crown-tribe relations. Yet even after declaring its own sovereignty the Crown continued ex necessitae to deal with Maori as a series of tribal polities that were imperia in imperio. Those dealings occurred in numerous ways, the various types being set out with great clarity by Richard Boast as what he terms cession agreements, confiscation agreements and regional pre-emptive agreements. He regards the last type as particularly important in demonstrating how the de facto independence of certain parts of the North Island in the latenineteenth century was ended by agreement or treaty. ${ }^{24}$ Certainly the Crown was dealing with the tribes of these regions on a quasi-diplomatic basis that had more to do with international relations

22 Richard Boast "Recognising Multitextualism: Rethinking New Zealand's Legal History" (2006) 37 VUWLR 547. The first half of this article rises in part to the challenge issued by this excellent article to consider the place of these lesser transactions between the Crown and tribes in our constitutional history.

23 Parata $v$ Bishop of Wellington (1877) 3 NZ Jur NS 72 (SC). I have followed the advice of Professor DV Williams on the correct naming of this case.

24 Boast "Rethinking Multitextualism", above n 22, 559. 
than domestic politics. Boast identifies the Fenton Agreement with Te Arawa (25 November 1880); the King Country negotiations and Aotea agreement (1883-85) and the agreement between the Crown and Tuhoe and other tribal groups of the Urewera (1895). ${ }^{25}$ The multiplicity of these treatylike arrangements means, Boast suggests, that we should speak of the Crown's "treaty partners" rather than "Treaty partners". ${ }^{26}$ Thus whilst New Zealand courts were insisting that there were no such things as tribes de jure and legislative policy was being formed on a racialised basis, the position de facto was very different. Perhaps the reality of the tribes was so menacing to the settler polity that its courts had to devise the comforting legal delusion of invisibility and its legislatures the policy of erasure?

By the beginning of the twentieth century, then, the Pakeha state was framing its conception of Maori people both individually and collectively in terms of race. Tribalism was seen not as a viable, so much as a passing, form of political practice that would go with the assimilation of the Maori individual into the white population. It was a racial attribute each Maori had to be encouraged to shed. There was a sense that the Government would continue to work through the tribes, but that was in order to weaken and eventually dissolve them. The racial element in New Zealand lawmaking crept in during the late-nineteenth century and was certainly in place by the time of the Native Land Act 1909. Drafted by Sir John Salmond, the Act gave a definition of "Native" as including "a half caste and a person intermediate in blood between half castes and persons of pure descent of the Native race." 27 The Electoral Act 1956, to give a more recent example to show the persistence of racialised treatment, also used blood percentage. It divided Māori into three categories distinguished by blood: those more than half Māori who were required to enrol on the special Māori electorate roll; those less than half Māori who were to enrol on the general European roll; with the intermediate category "half-castes" being able to chose either. Whilst that blood percentage approach could not operate in relation to succession to land (where descent applied), it was eventually abandoned in other spheres of Māori affairs (such as the electoral) in favour of a formula that simply required descent from a Māori person. ${ }^{28}$

25 Ibid.

26 Ibid, 581

27 Native Land Act 1909, s 2. See more fully McHugh Aboriginal Societies and the Common Law, above n 3, 274-6.

28 The Maori Housing Act 1935 defined a Māori as "a person belonging to the aboriginal race of New Zealand, and includes a person descended from a native." Also, for example, The Maori Purposes Fund Act 1934-35, s 2; The Maori Social and Economic Advancement Act 1945, s 2; The Maori Soldiers Trust Act 1957, s 2; The Maori Trust Boards Act 1955, s 2. The Maori Affairs Act 1953 maintained the 1909 definition. The Hunn Report [JK Hunn Report on Department of Maori Affairs: with Statistical Supplement, 24 August 1960 (Government Printer, Wellington, 1961)] advised retaining the 50 per cent quantum, adding that it might be extended in the future to three-quarter castes to limit the government's responsibility to Māori. Te Ture Whenua Maori Act 1993, s 3 and the Electoral Act 1993, s 3 use the simple hypodescent formula. See 
The wording of legislation that provided a vehicle for collective Māori action remained neutral on the tribal element that invariably and necessarily poured into those regimes. Implicitly tribalism was seen as a passing condition and the statutory regimes as essentially temporary arrangements pending, if not facilitating, that assimilation. Yet the viability that those statutory regimes experienced on the ground was a reflection of the intensity of tribal engagement and where that happened positively they became vehicles for Māori agency rather than assimilation. They worked if Māori wanted them to work, and particular tribes at particular moments in time at that. A wellknown example remains the success of Māori incorporations on the East Coast of the North Island amongst Ngāti Porou where the mana of Sir Apirana Ngata was and remains influential. Elsewhere the success of the incorporation has been much more chequered. Thus the effectiveness of statutory mechanisms was and today is still a function of their ongoing attractiveness (passing or permanent) to Māori whakapapa (genealogically-linked) groups. Without such support - as in the 1910s with the loss of mana of the Councils set up under the 1900 legislation ${ }^{29}$ - then the statutory regime became ineffectual, marginal or irrelevant in terms of the regional and local conduct of Māori politics. Legally the tribal polities might not have been there, but in point of fact their everconfiguring presence in Māori life remained central. The pattern of tribalised political relations that had began so flamboyantly with the Treaty and then atomised into lesser and localised transacting necessarily continued. Colonialism may have brought different forms of Māori collective action - or "teams", as Andrew Sharp has called them ${ }^{30}$ - outside (or drawing upon) whakapapa - but the tribe remained the core form of customary organisation. ${ }^{31}$ Whilst the primary agent in the settler-state's encounter with and management of the tribes might have eventually become the Māori Land Court, that was far from signifying their discontinuance. It signalled the Court's replacement of the Crown as the direct agent of state kawanatanga. And the history of the Court's relations with Maori during the twentieth century was certainly a highly tribalised one. After the Second World War urbanisation of the Māori population away from their tradition tribal regions was much more effective in weakening the pull of whakapapa and the fabric of the tribe than all the interfering of Pākehā legalism.

for a comparative discussion Toeolesulusulu Salesa "Half-Castes between the Wars: Colonial Categories in New Zealand and Samoa" (2000) 34 New Zealand Journal of History 98.

29 Roger Maaka "Perceptions, conceptions and realities: A Study of the Tribal in Maori Society in the Twentieth Century" (PhD thesis, University of Canterbury, 2004) on the loss of mana of the Councils in the southern Hawkes Bay region during the 1910s.

30 Andrew Sharp "Blood, Custom, and Consent: Three Kinds of Maori Groups and the Challenges they Present to Governments" (2002) 52 U Tor LJ 9.

31 Lyndsay Head argues that western colonialism with its state-centred notions of sovereignty lubricated changes to Māori political thought and action from a basis in mana (pre- and early-contact) to whakapapa: "Land, Authority and the Forgetting of Being in Early Colonial Maori History" (PhD Thesis, University of Canterbury, 2006). 
By the early to mid-1970s, then, a common theme had formed in the common-law jurisdictions of North America and Australasia in terms of the legal conceptualisation of their indigenous peoples. New Zealand fitted that trend squarely. The position of Māori, as with other indigenous peoples, continued to be articulated in racialising terms and their presence in the legal system largely characterised negatively through norms of non-discrimination. By that time the national legal system had given Māori the right not to be discriminated against in terms of the ways Pakeha saw them - as a race. But still it did not validate or authorise their culture and political presence in the tribalised way Māori actually organised and saw themselves, except to the extent that particular tribes had been able to turn specific statutory mechanisms - the incorporation and the trust board especially - to their own ends. That pattern of co-option and adaptive absorption of Pākehā legalism into the tribe was no more than patchy. Law still said that Māori would exist as it determined, rather than as they actually were. They continued to be seen and treated at law in terms of a simplistic conceptual category - race - that was not theirs, not in the Treaty, and never agreed to by them as the foundation for constitutional relations or their legal depiction.

\section{THE END OF THE RACIALISED PARADIGM}

So when and how did race disappear? When and by what means did the common-law legal systems begin seeing tribal societies as they actually saw and organised themselves? The governments and agents of at least three jurisdictions - the United States, Canada and New Zealand - had a historical pattern of transacting with its aboriginal peoples on the basis of their tribal organisation whilst trying, through state law, to deal with them en bloc as a race. When did the legal systems stop informing tribal societies that they were as the white man saw and defined them but, instead, more as they actually were - a series of tribes, each different and carrying its own history of engagement with the Anglo-settler state and other polities (neighbouring tribes, especially) as well as its own history of itself as a political being, rather than a monolithic race of individuals afflicted by anachronistic tribalism?

In Morton v Mancari (1974) the United States Supreme Court had to consider the impact of the Equal Employment Opportunity Act $1972^{32}$ on the employment preference for Indians in the BIA (Bureau of Indian Affairs) under the Indian Reorganization Act 1934. ${ }^{33}$ The 1972 statute proscribed discrimination in federal employment practices on the ground of race. The federal policy of preferring Indian employees extended back to 1834 and had been renewed by Congress in numerous statutes, including most prominently the 1934 Act. The Court noted that the purpose of those preferences "as variously expressed in the legislative history" had been "to give Indians a greater participation in their own self-government; to further the Government's trust obligation toward the

32 Morton v Mancari (1974) 417 US 535; Equal Employment Opportunity Act 42 USC § 2000 and following.

33 Indian Reorganization Act 193425 USC $\S 472$. 
Indian tribes; and to reduce the negative effect of having non-Indians administer matters that affect Indian tribal life." 34 The Court held that this was not a case of racial discrimination: ${ }^{35}$

Indeed, it is not even a 'racial' preference. Rather, it is an employment criterion reasonably designed to

further the cause of Indian self-government and to make the BIA more responsive to the needs of its constituent groups. It is directed to participation by the governed in the governing agency.

The Court held that the federal employment preference, as applied, was granted to Indians "not as a discrete racial group, but, rather, as members of quasi-sovereign tribal entities whose lives and activities are governed by the BIA in a unique fashion." ${ }^{36}$ It was an outcome of the historical and ongoing pattern of political relations between the tribes and the federal government.

The American approach in Morton v Mancari was one that deliberately stepped out of the racial paradigm and into a constitutional characterisation more attuned to the history of federal relations with the various tribes. It linked recognition of the tribe as a juridical entity to the distinctly American doctrine of inherent and residual tribal sovereignty (albeit one subject to the Congressional plenary power to legislate). The Supreme Court confirmed that trend in the highly important case Santa Clara Pueblo v Martinez. ${ }^{37}$ In this case the doctrine of tribal sovereignty (in this case to determine tribal membership) was reinvigorated, leading amongst other things to a renaissance of on-reserve tribal courts. Many remain ambivalent about the legacy of Martinez, but it certainly affirmed the tribal axis of mainland federal Indian law and relations. Commentators on the development of that law under the Rehnquist Court have noted its marked tendency towards minimalising the scope of tribal authority whilst at the same time re-averring the foundational principle. ${ }^{38}$ In that respect many commentators have seen the Court's recent position in Rice $v$ Cayetano $^{39}$ as a negative exception (though consistent with the minimalising trend). The Court shunned the history of American governmental dealings with the native Hawaiian polity (including collusion in its removal in breach of international law) in favour of a racially-oriented characterisation of their status. ${ }^{40}$ The damage done to institutions specifically serving Native

34 Morton v Mancari, above n 32, 541-2 Blackmun J for the Court.

35 Ibid, 543-4 Blackmun J for the Court.

36 Ibid, 554 Blackmun J for the Court.

37 Santa Clara Pueblo v Martinez, above n 18.

38 David Getches "Conquering the Cultural Frontier: The New Subjectivism of the Supreme Court in Indian Law" (1996) 84 Cal L Rev 1573 and David Getches "Beyond Indian Law: The Rehnquist Court's Pursuit of States' rights, Color-Blind Justice and Mainstream Values" (2001) 86 Minn L Rev 267.

39 Rice v Cayetano (2000) 528 US 495.

40 William Spruill "The Fate of the Native Hawaiians: the Special Relationship Doctrine, the Problem of Strict Scrutiny, and Other Issues Raised by Rice v Cayetano" (2001) 35 U Rich L Rev 149. 
Hawaiians may be widespread. ${ }^{41}$ Thus even whilst the American jurisprudence showed a clear principle of tribalised relations, there remained the temptation to go against the clear grain by resorting to simplistic ahistorical racialisation.

Anglo-Commonwealth jurisdictions, with their rigid notion of singular and indivisible Crown sovereignty, have never been able to accept the American doctrine of inherent tribal sovereignty. However, because these legal systems did not, or rather avowed they could not, recognise the tribe as a residual and subordinate sovereign did not mean that the tribe should continue to have no legal identity whatsoever inside the Anglo-Commonwealth legal systems. The wilful refusal to accept the tribe as a juridical as well as cultural reality that marked the loyalist jurisprudences of the nineteenth and much of the twentieth century began to collapse in the 1970s. Implicitly the national common law accepted that the tribes were rights-bearing juridical entities. The national courts accomplished this without taking an American-like approach and constructing the tribe as a residual sovereign. Sovereignty-talk was not needed. The tribe was simply recognised as a juridical entity arising from the continued reality of its presence and customary organisation. This step was, of course, consistent with the more liberal approach being taken at large by those common-law courts towards justiciability and standing. In shedding the exclusionary approach of yore, the loyalist courts moved the national jurisprudence out of the racial paradigm into one that tended towards the historical and tribalised approach of the American jurisprudence, minus the sovereignty element.

In all jurisdictions the first breakthrough was a mostly unnoticed procedural one by which courts allowed tribal peoples to commence class actions on claims related to tribal interests. That in turn allowed the courts to recognise the tribal proprietary right through what became known as the common-law doctrine of aboriginal title. This title vested in the tribe whether as a result of their factual presence on their lands at the time of Crown sovereignty (the Canadian approach) or as a result of their customary legal system operating over that land at the time of Crown sovereignty through to the present (the Australian). ${ }^{42}$ This form of ownership implied the tribal owner had juridical identity but in both legal systems the elaboration of that identity has tended in opposite directions. In Canada aboriginal title has been linked to self-government - a kind of outward expansion from the notion of tribal ownership. That link has been strengthened by the formal acknowledgement by the federal Government in 1995 that First Nations had the inherent aboriginal right to self-government. ${ }^{43}$ In Australia, however, the Howard Government doggedly prevented that

41 The case has resulted in other state-established institutions with a specific mandate for Native Hawaiians becoming prone: Carroll v Nakatani (2002) 188 F Supp 2d 1233 (D Haw); Arakaki v Lingle (2005) 423 F 3d 954 (9th Cir); (2006) 126 S Ct 2861; Doe v Kamehameha Schools (2005) 416 F 3d 1025 (9th Cir).

42 On the different national approaches see McHugh "Aboriginal Title in New Zealand", above $\mathrm{n} 1$.

43 Indian and Northern Affairs Canada Federal Policy Guide: Aboriginal Self-Government (Minister of Indian Affairs and Northern Development, Ottawa, 1995) available at www.ainc-inac.gc.ca (accessed 1 September 2007). 
enlargement of the proprietary right. It used the native title legislation to constrict the juridical compass of tribal ownership to self-management.

Here one reaches an important difference between the Australian jurisprudence on the one hand and the Canadian and New Zealand on the other. In Australia governmental relations with Aborigines are constitutionally racialised. Section 51(xxvi) of the Constitution was amended as a result of a referendum in 1967 following which the following bracketed words were removed. ${ }^{44}$ The Commonwealth took power to make laws for "the people of any race [, other than the Aboriginal race in any State,] for whom it is deemed necessary to make special laws." 45 This is the basis for Commonwealth law, such as the crucial Race Discrimination Act 1975, which prevents states from passing laws that discriminate negatively against Aborigines. Because of this wording the case law on the scope of section 51(xxvi), which did not begin until the early 1980s, necessarily took and keeps a racial orientation. ${ }^{46}$ That disposition is further complicated by the absence in Australia of a history of political relations between the Crown and Aboriginal nations shown by the treaty-making patterns of Canada and New Zealand. Indeed, by insisting that Aboriginal tribes, including those holding land under a confirmed native title, have no more than a right to self-management, the Australian Government has resolutely refused to enter into a similar history of political relations that Canada and New Zealand have experienced throughout their national existence. ${ }^{47}$

In Canada the jurisprudential foundation for aboriginal and treaty rights in the modern era has not been race. There the conduct of comprehensive and specific claims as well as self-government negotiations - that is, a governmental practice - as much as court judgment has been premised upon the political distinctiveness of each First Nation. Indeed, the federal First Nations Governance Bill

44 Robert Sadler "The Federal Parliament's Power to Make Laws 'With Respect to ... the People of any Race'" (1985) 10 Syd L Rev 591, 596.

45 Constitution Alteration (Aborigines) Act 1967 (Cth), repealing s 127 as well as amending s 51(xxvi).

46 Koowarta v Bjelke-Petersen (1982) 153 CLR 168; Commonwealth v Tasmania (1983) 158 CLR 1 (on this see McHugh Aboriginal Societies and the Common Law, above n 3, 398-400). Later case law dealt with the consequences of native title: see 487-9 and Western Australia v Commonwealth (1995) 183 CLR 373; Kartinyeri v Commonwealth (1998) 152 ALR 540.

47 In my view, the predicament of Aboriginal peoples in Australia is so dire because they are dealt with almost entirely as a matter of race. There is a strong governmental resistance to grasping then building a series of relationships with their natural political forms - as through the Indigenous Land Use Agreement mechanisms of the native title legislation. The forms of representation that have been statutorily established, as with the now abolished ATSIC (Aboriginal and Torres Strait Islander Commission) and land councils under the Aboriginal Land Rights (Northern Territory) Act 1976 have been problematic because of their neglect of natural Aboriginal political groupings and alliance. From a nascent history of political relations more attuned to the realities of Aboriginal politics there might grow a jurisprudence like that of Canada and New Zealand. However that is a prospect from which white Australia seems instinctively to recoil. Further see M Langton and L Palmer, "Modern Agreement Making and Indigenous People in Australia: Issues and Trends" (2003) 8 AILR 1; M Tehan "A Hope Disillusioned, an Opportunity Lost? Reflections on Common Law Native Title and Ten Years of the Native Title Act" (2003) 27 Melb U LR 2. 
proposing a standardised, though interim, governance model for all Nations was expressly rejected by the First Nations who refused to be treated on a monolithic, one-size-fits-all basis. ${ }^{48}$ The rhetoric of that rejection had a ring very similar to that surrounding the Runanga Iwi Act 1990 controversy in New Zealand a decade before, when Māori also rejected a standardised governance model.

In 1999, in a case uncannily similar to the contemporaneous New Zealand litigation surrounding the fisheries allocation and urban Māori, the Supreme Court considered an agreement between Ontario and First Nations bands. By the agreement profits from on-reserve casinos would be used to strengthen band economic, cultural and social development administered through a First Nations Fund. The appellants (who included the Congress of Aboriginal Peoples) were told (1996) that Provincial non-status Indians and Métis were ineligible for the Fund, which was limited to Indian Act bands and their status members. At first instance, the Province's exclusion of the appellants was ruled an unconstitutional violation of their equality rights under section 15(1) of the Charter and that the Province had acted ultra vires section 91(24). The appellate courts disagreed. The Supreme Court explained: 49

The casino project was undertaken by Ontario in order to further develop a partnership or a "government-to-government" relationship with Ontario's First Nations band communities. It is a project that is aimed at supporting the journey of these aboriginal groups towards empowerment, dignity, and self-reliance. While it is not designed to meet similar needs in the appellant aboriginal communities, its failure to do so does not amount to discrimination under s 15.

The Court's reasoning was that this was an agreement about the use of band property (on-reserve casinos) rather than a pan-aboriginal settlement for the Province that was worded and administered in a discriminatory and unequal manner. The Fund's purview was that of the Indian Act First Nations (organised as bands) and its members, and not the broader community of Provincial aboriginals. Essentially, the Court characterised the traditional polity as the right-holding body rendering (as it were) the consideration for the agreement. The reasoning echoed Morton $v$ Mancari by characterizing the relationship being made by the Provincial Crown as one involving a political body (or series of them) in partnership rather than a racial group at large.

In June 2006 the British Columbia Court of Appeal gave judgment in $R v$ Kapp. ${ }^{50} \mathrm{~A}$ group of non-Aboriginal fishers were charged with illegally fishing at a time when a specific group of Aboriginal fishers were permitted to fish under a communal license. The accused argued that the federal government licensing policy was discriminatory, race-based and unconstitutional because their equality rights had been breached. The Court dismissed the appeal in five separate judgments,

49 Lovelace v Ontario [2000] 1 SCR 950.

$50 R v$ Kapp [2006] CNLR 282 (CA, BC). 
concluding that the licensing policy was not discriminatory and that the issuance of the First Nation communal fishing licence, designed to increase economic opportunities for Aboriginal peoples, did not breach the equality rights of non-Aboriginal commercial fishers. In short, aboriginal and treaty rights were not race-based but a response to the special constitutional position of First Nations as distinct polities inside Crown sovereignty.

The juridical foundation in North American jurisdictions for governmental relations with and treatment of aboriginal peoples rests on the ongoing history of political relations with customary polities. Race has been rejected as the foundation of those relations.

\section{NEW ZEALAND MOVES BEYOND THE RACIAL PARADIGM (1985-) AND BUILDS A NEW TRIBALISED AND CONSERVATIVE JURISPRUDENCE OF MAORI AFFAIRS}

During the 1980s the New Zealand jurisprudence moved away from the racial paradigm that was still was there in the 1970s. How did that happen? This occurred in a number of ways, some but not all of which involved the judicial and tribunal elaboration of Treaty principles. The deracination and tribalisation of the Māori jurisprudence occurred on several fronts other than by means of the statutory recognition of Treaty principles, although that surely oiled the process.

For a start, whakapapa as manifest in iwi and hapū remained the dominant cultural phenomenon surrounding the exercise by the Maori Land Court of its statutory jurisdiction under the old Maori Affairs Act 1953. Whilst the Act had been cast in neutral and ostensibly racialised terms, the actual operation of its provisions had been highly conditioned by the tribal nature of Māori society. And in that regard t'was ever thus. The revision of this legislation in Te Ture Whenua Maori Act 1993 enabled greater acknowledgement and more facilitative accommodation of the whakapapa nature of Māori society in such matters as constitution of trusts and prescription of the preferred class of alienees of Māori freehold land. This revision occurred with only the most passing of references to the Treaty of Waitangi in the Preamble of the Act, a reference so minor and passing that the Principles of the Treaty Principles Deletion Bill with its schedule of offending statutory references let it go.

The common-law doctrine of aboriginal title also had an impact in New Zealand. In Te Weehi v Regional Fisheries Officer ${ }^{51}$ the conviction of a Ngāti Porou man, Tom Te Weehi, under the Fisheries Act was quashed on the ground that he was exercising a common-law customary fishing right in accordance with tikanga o te Ngai Tahu as spared under section 88(2) of the Fisheries Act 1983. This case was not appealed, a result, some said at the time, of anxiety in government circles of Sir Robin Cooke's Court endorsing and extending the judgment along the lines of the American

51 Te Weehi v Regional Fisheries Officer [1986] 1 NZLR 682 (HC). 
Boldt cases (1974 and 1979). ${ }^{52}$ Nonetheless, Te Weehi was an important backdrop to the commercial sea fisheries settlements of 1989 and $1992 .{ }^{53}$ It raised the spectre of common-law rights in the context of a Court of Appeal then generally perceived (especially in Government) as highly sympathetic to Māori claims as evident in the then fresh Maori Council cases. Before the passage of the settlement legislation with its provision for taiāpure (customary) fisheries, several cases invoked tribal tikanga in applying the section $88(2)$ exemption of common-law customary fishing rights. ${ }^{54}$ After the passage of the legislation there followed twelve years of intense political contestation within Maoridom as to the distribution of the income from the fisheries allocation, disputation settled (though not, one suspects, permanently) in the Maori Fisheries Act 2004. ${ }^{55}$ The fisheries settlements were concluded in what the modern (that is to say, snail's) pace of claims settlement would regard as an unseemly rush.

The commercial sea fisheries settlement was ostensibly with "Māori" but by the early 1990s any depiction of them as a racial bloc was impossible. The Fisheries Allocation saga never entailed, or even suggested, definition of Māori as a race. Such a possibility was never in the frame. Rather, it was a question of defining their political form. When urban groups, self-identifying as Māori, intervened and claimed the right to partake in the settlement, Pākehā courts were called upon to determine who the "Māori" were that held the benefit of the settlement. By that time international law had moved towards recognition of the right of self-identifying aboriginal individuals and groups to have their ethnic status protected positively by the state. The foundation of this right was indigenous peoples' ethnicity (self-identifying practices) rather than their race. ${ }^{56}$ That is to say,

52 United States $v$ Washington (1974) 384 F Supp 312 (WD Wash), affirmed at (1975) 520 F 2d 676 (9th Cir). See more recently United States $v$ State of Washington (1998) 157 F 3d 630 (9th Cir) (shellfish). In a highly controversial series of judgments, it was held that the right to fish held by tribes of the Pacific North West of America under treaty with the federal government entitled them to 50 per cent of the allowable catch. These cases were also being talked up before the Waitangi Tribunal: Muriwhenua Fishing Claim Report: Wai 22 (Waitangi Tribunal, Wellington, 1988) paras 9.1.2 and 9.2.5.

53 Maori Fisheries Act 1989 and Treaty of Waitangi (Sea Fisheries) Settlement Act 1992. For background see R Dawson "The Genesis of the New Zealand Parliament's Treaty of Waitangi (Fisheries Claims) Settlement Act 1992" (2000) 1 International Journal of Water 80 and Richard Boast "Maori Fisheries 1986-1998: A Reflection" (1999) 30 VUWLR 111. See also DV Williams "Customary Rights and Crown Claims: Calder and Other Canadian Contributions to the Revival of the Doctrine of Aboriginal Title in Aotearoa New Zealand" (a paper prepared for seminar "Let Right Be Done: Calder, Aboriginal Rights and the Treaty Process: Looking Forward, Looking Back", University of British Columbia, 2005).

54 MAF v Love [1988] DCR 370 (DC); MAF v Hakaira \& Scott [1989] DCR 289 (DC); Green v MAF [1990] 1 NZLR 411 (HC); Rawere v MAF (1991) 6 CRNZ 693 (HC); Paku v MAF [1992] 2 NZLR 223 (HC).

55 See Tāne Waetford "The Māori Fisheries Act 2004: Will it Finally Settle the Māori Fisheries Ssettlement Scheme?" (LLM Research Paper, Victoria University of Wellington, 2006).

56 I explained the legal basis for this standard in PG McHugh "Aboriginal Identity and Relations in North America and Australasia" in Ken Coates and PG McHugh (eds) Kokiri Ngatahi: Living Relationships - The Treaty of Waitangi in the New Millenium (Victoria University Press, Wellington, 1998) 107-186. Bizarrely 
indigenous polities were self-identifying rather than self-identified. Forced to identify the "Māori" of the fisheries settlement the courts might have taken that internationalised approach. They might have recognised Māori as a dynamic and fluid ethnie comprised primarily of tribes or iwi organised by whakapapa (and ramifying into hapū) but with new and still emergent urban groups formed around kaupapa (non-genealogical association). This approach was implicit in Sir Robin Cooke's comment regarding separate provision for urban Māori in allocation of the benefit of the settlement. As this saga unfolded, the courts did not take that approach but the more conservative one. They regarded Māori as comprising entirely a bloc of iwi, admittedly with responsibility for their urbanised members, but still the same series of political formations that had signed the Treaty of Waitangi and entered into historical relations with the Crown. ${ }^{57}$ Thus the more fluid approach that Sir Robin Cooke had signalled - though admittedly no more than raised, much less explored fully in the light of those international norms - was rejected.

This was an historical juncture from which a more elastic notion of Māori political forms might have entered the New Zealand legal system. This would have been a difficult and turbulent jurisprudence, and doubtless a controversial one. It may well have become a tiger caught by its tail, impossible to manage, requiring the juridical characterisation of Māori political fluidity that probably defied such analysis with its stagnating, freeze-framing tendencies. When, however, the substantive issue of fisheries allocation returned to the courts the moment, like the retired Sir Robin, had gone. Such, by then, was the dominance of iwi that a more extended juridical notion of Māori collective action extending beyond though dominated by whakapapa did not appear. The definition of Māori political being in terms of iwi and whakapapa was certainly a safer, less jurisprudentially hazardous course. By taking that route the courts supplemented the historic claims process and accentuated the phenomenon some commentators have described as the "re-tribalisation" of Māori culture. ${ }^{58}$ By the late 1990s that re-tribalisation was irreversible and deeply entrenched in New Zealand political life and constitutionalism.

As I have been stressing and as the fisheries settlement and activity of the Maori Land Court were showing, the retribalisation of Māori jurisprudence that was becoming evident in the early 1990s was occurring through legal means other than wholly via statutory references to "the principles of the Treaty of Waitangi". Indeed, until the mid-1980s, there was very little by way of a jurisprudence of Māori rights, other than (as I mentioned earlier) one of neglect and inside the specialist jurisdiction of the Maori Land Court. In the late 1980s when the New Zealand courts

some commentators misread my description of the standard applied at international law as advocating the end of whakapapa.

57 Te Runanga o Muriwhenua v Te Runanganui o Te Upoko o Te Ika [1996] 3 NZLR 10 (CA); Treaty Tribes Coalition v Urban Maori Authorities [1997] 1 NZLR 513 (PC).

58 Steven Webster "Maori Retribalization and Treaty Rights to the New Zealand Fisheries" (2002) 14 The Contemporary Pacific 341; Maaka "Perceptions, conceptions and realities", above n 27. 
seemed about to embark upon the exercise of giving Māori greater presence in the legal system, some thought it might be a question of Treaty rights (as included in statutory regimes) or aboriginal rights (emanating from the common law). ${ }^{59}$ In the end it was a combination of both, although the jurisprudence did not become as far-reaching and pervasive as seemed in prospect at that time. And it has grown into an essentially conservative form.

Nonetheless when that Māori jurisprudence started to expand it inevitably reflected the tribal character of their society. There is no doubt that Parliamentary willingness to incorporate Treaty principles oiled that process considerably. It elevated the importance of the historic claims process that began with the extension of the Waitangi Tribunal's jurisdiction in 1985. The interpretation of those principles, as set out in section 9 of the State-Owned Enterprises Act 1986, by the Court of Appeal in the Maori Council cases ensured that claims-resolution would be a national priority rather than a quiet diversion of no more than peripheral national attention. And being historic it was plain that those claims vested in the historical tribal groups upon whom Crown transgression had been visited. That vesting of right meant that the older and more traditional whakapapa forms of Māori political representation were renewed and revitalised by the prospect of significant asset restitution. Re-tribalisation was augmented considerably by, indeed some might even say it was an outcome of, the Treaty settlement processes. In that regard there was an inherently conservative element in the dominance that the claims process took in Māori politics and their relations with the state from the mid-1980s and especially from the early-mid 1990s when that process began to reach full momentum.

Re-tribalisation could only have led to a conservative jurisprudence. It was conservative in the sense that it meant the revalidation - the conservation - of the historical pattern of political relations between the Crown and its treaty partners. Claims resolution called for contemporary treaty-making with the traditional polities. It was conservative in another sense. The tribe is a political formation of human beings in which authority is determined by age and mana. By its very nature that kind of polity will be conservative, especially given the strong seam of indigenised Christianity that runs through most. ${ }^{60}$ The claims process has shored up and consolidated the authority of the traditional leaders of iwi.

Further, the claims-settlement processes have required the tribes to organise on a legally more secure basis than mere tribalism alone. Customary organisation alone will not suffice in the new era of aboriginal asset-management. Before millions of dollars of assets are vested in the claimant tribe

59 Richard Boast "Treaty Rights or Aboriginal Rights?" [1990] NZLJ 32.

60 On aspects of which see Richard Boast "'In Satan's Time': Missionaries, Land Alienation and Customary Law in 19th-century New Zealand" in (1998) Spectrum, stressing that by the mid-nineteenth century many had "come to equate pre-Christian customary practice quite literally with the Government of Satan." See also John Stenhouse "God's Own Silence: Secular Nationalism, Christianity and the Writing of New Zealand History" (2004) 38 New Zealand Journal of History 52. 
the governments of all North American and Australasian jurisdictions have insisted that legal entities are put in place to manage those assets on principles of transparency and accountability (political as well as financial). Tribes have been required to keep membership rolls, so that customary processes of membership become textualised and re-oriented on a more formal, less fluid basis. ${ }^{61}$ This juridification of the tribe on a basis in which custom plays alongside and is in many respects subordinated to new textualised codes necessarily has a conservative impact. It consolidates and centralises the authority of those who drive the codes, at the same time overlaying and diluting (though it could never oust completely) the authority and dynamism of custom. Textual enclosure, even if partial, has an inherently containing and conservative impact upon the group, especially those of Māori whose forms of Polynesian political practice historically have shown a high degree of adaptability and fluidity.

One may speculate the future consequences for Māori political forms and practice ensuing from the contemporary and ongoing re-accentuation by Māori and the settler state of the rights-bearing tribe. This is the setting for a future web of histories, a series of group-based experiences that will both shape (as in, indigenise) and be shaped by (as in, reinscribe the colonialism of) national politics and constitutionalism. Certainly the current emphasis upon the tribe is channelling - and may even be stifling - the political practices of a people whose history shows their receptivity and adaptability to new forms of inter-cultural engagement. The paradox is that this quality is being downplayed, if not suppressed, in the contemporary Māori jurisprudence and the form of claims-based engagement with the settler-state where historical authenticity is given a premium. ${ }^{62}$ And as I noted earlier, the juridical opportunity that Sir Robin provided in the fisheries allocation case was not taken. It is impossible now to gauge the wisdom or otherwise of that choice: My point is that it was a safe and conservative one that generated a matching jurisprudence.

The concept of partnership has been identified as a Treaty principle, but it is really a treaty principle, in that the concept was implicit in all the treaty and other post-1840 relations between Crown and tribe. Partnership, wherever one sourced it, gave the Tribunal and Court of Appeal a juridical way to acknowledge the reality of the tribe in a manner sensitive both to the history of Crown relations and the demands of the present. It was invoked without recourse to the problematic

61 For instance Linda Waymouth "The Bureaucratisation of Genealogy" (2003) 6 Oceanie available at http://recherche.univ-montp3.fr (accessed 1 September 2007).

62 To comment briefly, this is one of the outcomes of colonialism and the history of Māori engagement with western legalism with its reductionist and totalising tendencies, where one customary trait - genealogical association (whakapapa) - is set against and put in binary competition with another - political dynamism. In that way the state, and its legalism, reinscribes its authority over Māori. This observation has the makings of a radical critique of that legalism, a critique that has been implicit in my work for the past few years but one that I have been prepared to leave to others less inside the rights-discourse. My point is the vastly safer one: Tribe-based participation in that discourse, which now is a fact of Māori life, has had an inherently conservative impact upon their political practices inter se. 
language of sovereignty. The formulation of Treaty principles in these fora, notably the Crown's duty of "active protection", acknowledged that this was an asymmetrical partnership; however the Tribunal and courts were insistent that this was also one in which dialogue was important. The outcome of the first so-called Lands case itself indicated that. The Court of Appeal instructed the parties to negotiate an interim arrangement to allow both corporatisation of state assets and their availability for the eventual settlement of historic claims. In the event of agreement not being reached, the Court reserved the right to impose its own arrangement. In the event that proved unnecessary. ${ }^{63}$ With these modern agreements - the Lands and fisheries settlements - there resumed between the Crown and iwi the historical pattern of direct political relations. This now overlaid, and in many respects over-shadowed, the more low-key and more specialised accommodation of tribal identity inside the jurisdiction of the Maori Land Court.

That pattern of political relations also arose from the historic claims process, the integrity of which the Maori Council cases had sought to ensure. Indeed that pattern was resuming even whilst claimants were presenting historic claims to the Tribunal under its recently-widened jurisdiction. The late Sir Robert Mahuta astutely decided to bypass the Tribunal process altogether and commenced direct negotiations with the Crown on the Tainui confederation's raupatu (confiscation) claim. ${ }^{64}$ Tainui reached settlement in 1995, three years before the first major historic claim, the huge Ngai Tahu claim, was settled in 1998. Yet claimants equipped with a Tribunal Report on their historic claims have always had to enter into direct negotiation with the Crown given that the Report issued "recommendations". The Tribunal has been reluctant to enter into a remedies jurisprudence forcing the hand and pace of settlement negotiations - although there has emerged the makings of one $^{65}$ - seeing these negotiations as a matter of partnership. This is an arms-length posture taken also by the courts. Nonetheless the historic claims settlement process represents a mechanism by which claimant iwi and hapu enter into direct dialogue and agreement with the Crown. They do so not as "Māori", a racial group, but as members of a political entity that has suffered in its historical treatment by the Crown.

There has been another important site of that engagement and that has been under the tangata whenua provisions of the Resource Management Act 1991 (RMA). These provisions were squarely

63 New Zealand Maori Council v Attorney-General [1987] 1 NZLR 641 (CA). The eventual negotiated agreement with its "claw-back" provisions was legislated as the Treaty of Waitangi (State Enterprises) Act 988.

64 Part of Sir Robert's strategy included the bringing of myself and Benedict Kingsbury, both of us junior academics in Cambridge and Oxford respectively, to New Zealand in 1989 for a series of presentations on the emergent jurisprudence of aboriginal rights at common law (myself) and international law (Benedict). Sir Robert sensed the Government was nervous about the direction the law might take, and told us that he wanted to fuel and use that anxiety as leverage to move into direct negotiation.

65 See Waitangi Tribunal Te Whanganui-a-Orotu Report: Wai 55 (Waitangi Tribunal, Wellington, 1998) and Turangi Township Remedies Report: Wai 84 (Waitangi Tribunal, Wellington, 1998). 
in the firing line of the Treaty Principles Deletion Bill. Certainly the early experience of the tangata whenua provisions was bumpy and a considerable body of case-law developed on the "who", "what" and "how" of consultation with iwi. However after an early flurry that activity had settled down with the case-law providing substantial guidance on how iwi fitted into the RMA scheme, especially with regard to their involvement in applications for resource consent. ${ }^{66}$ Further, recent studies by the Te Puni Kōkiri (TPK) have found that the consultation procedure was not necessarily a substantial drag where local authorities had built and maintained good relationships with local iwi. The real problem that TPK uncovered in relation to the statutory involvement of iwi in the RMA processes was not the "unreasonable" invocation of Treaty principles to block planning and resource consents, as sensationalist media attention to taniwha (sea and river monsters) seemed to suggest. The studies showed that Māori values were not necessarily incompatible with resource development. ${ }^{67}$ Rather the problem was one of the capacity and capability of iwi to participate meaningfully and cooperatively in the process. ${ }^{68}$ In that regard the picture was a patchy and regionalised one. The problem was not Māori participation so much as their inability to do so effectively. If one were to implicate the Treaty principles in that result, it would be to see it as an expression of their failure rather than their invocation. If the Treaty principle of partnership were operating properly, then the iwi consultation requirements would not be problematic. The 2005 amendment to the RMA removing the requirement of iwi consultation for resource consent applications and limiting it to the broader policy-setting levels of Policy Statement, and formation of District and Local Plans has in any event taken any steam there was out of this area. The deeper problem of iwi capacity and capability remains. And again, looking at the profile of the RMA jurisprudence one is struck by its inherent conservatism. The issues have been less the disruptive impact of Māori spiritualism than the process-related questions of enabling Māori to play a meaningful role. This has not been a radical or activist jurisprudence but one where issues of process rather than principle have pressed hardest.

In addition, one feature of the engagement of claims resolution processes with resource management issues has been the use of co-management regimes to give aboriginal peoples ongoing participation and voice in matters that often bear closest upon their identity and association with traditional land. These regimes have been used in North America and to some extent in Australia,

66 I discuss that case law in "Living with Rights Aboriginally: Constitutionalism and Maori in the 1990s" in Michael Belgrave, Mereta Kawharu and David Williams (eds) Waitangi Revisited - Perspectives on the Treaty of Waitangi (Oxford University Press, Auckland, 2004) 283.

67 Robert Joseph "Maori Values and Tikanga Consultation under the RMA 1991 and the Local Government Bill - Possible Ways Forward" (a paper presented to Inaugural Maori Legal Forum Conference, Te Papa Tongarewa, Wellington, 9-10 October 2002).

68 Te Puni Kōkiri Te Kotahitanga o te Whakahaere Rawa - Maori and Council Engagement under The Resource Management Act 1991 (Te Puni Kōkiri, Wellington, 2006). I am grateful to Arnu Turvey who played a role in this report and brought it to my attention. 
although, so far as one can generalise, their experience and success have been patchy. Comanagement can be pitched at a series of levels ranging from rights to be consulted (lower level) through to rights of co-decision (upper level). In New Zealand co-management has not been formally recognised as one of the options available in settlement packages, although there have been some arrangements that resemble a form of it. ${ }^{69}$ It may become a device that finds more widespread use, but if that happens, the responsible Māori group will surely be the traditional territorial iwi.

By now my belief will be plain. To the extent there has grown a jurisprudence of Treaty principles it has been an inherently conservative one. Far from pushing the boundaries of that jurisprudence the courts have been cautious and more concerned with ensuring due process. The profile of the jurisprudence has been facilitative, geared mostly around getting the relevant parties in constructive dialogue within the terms of the statutory regime. The courts have not engaged in some fanciful fluffing-up of the principles of the Treaty of Waitangi. Certainly the jurisprudence has for the most part become low-key and below the public sightline. The description of it in the Bill before Parliament as "increasingly" activist was plainly wrong. One cannot pretend there have not been problems, but very few of those originated directly from the statutory application of Treaty principles.

Here one might pause and comment that the most important manifestation of those political relations - the historic claims settlement process - is non-statutory. Though the Waitangi Tribunal operates under a statutory mandate the actual post-Tribunal mechanism for resolution of validated historical claims does not have a legal foundation. Further, it might be noted that the courts have resolutely refused to intervene in those settlement processes on administrative law grounds. Likewise the RMA structure has been resistant to the injection of administrative law principles. ${ }^{70}$ Some have seen that cautious, arms-length approach as reviving the "political question" doctrine of non-justiciability associated with the Parata case. ${ }^{71}$ In other words, the reasoning runs, there may have been a renewal of political relations between Crown and iwi but those remain exactly that political dealings inhabiting an extra-legal zone.

However, there are important differences from a century ago, particularly if one considers contemporary relations in the light of the claims-settlement process. First, whilst the courts have indicated their willingness to intervene to ensure the inherent fairness of the settlement process and to see that all claimants obtain the Crown's ear, generally they have seen the principle of partnership

69 See Arnu Turvey Rights Integration - Co-management Regimes and Resource Management (LLM Research Paper, Victoria University of Wellington, 2006).

70 For example Te Runanganui O Taranaki Whanui Ki Te Upoko O Te Ika A Maui Inc v Wellington Regional Council (8 July 1998) ECt WN W48/98 (the "Wellington Biosolids" case).

71 DV Williams "Wi Parata is dead, Long Live Wi Parata" in Claire Charters and Andrew Erueti (eds) Maori Property Rights and the Foreshore and Seabed: The Last Frontier (Victoria University Press, Wellington, 2007) 31 . 
as leaving the conduct of the process to the parties themselves. The fact that this process is not set out by law does not mean that it is inherently unstable and irregular. Indeed the experience of claimant groups in this new century seems to be the opposite - that it is grindingly and relentlessly regular in its operation. The crucial difference between now and the then of the Parata case is that there is no juridical obliteration of the tribe. Unlike Prendergast CJ's insistence that the tribes are not there, the foundation of the new "political question" doctrine is the acceptance that they very much are - the invisible tribe no longer. The principle of non-justiciability does not mean an absence of public law consequence. Rather, it means the courts will not be the sole or primary agent of that consequence in the claims-settlement arena. Crown-tribe relations occur inside a sphere governed by extra-statutory procedure (as set out in the Office of Treaty Settlement's "red book" of settlement procedure) and tikanga in which the constitutional actors themselves, Crown and iwi, maintain their historical interaction and apply a unique internalised legalism. ${ }^{72}$ Call this government-togovernment, nation-to-nation, or partner-to-partner relations, but the reawakening and pursuit of those relations has become in the past twenty years the embedded "realism" of New Zealand's constitutional arrangements, constructed as they are through a myriad of hard and soft laws of which "Treaty principles" are but a segment (though an important one). The constitution is not solely a matter of what the courts are doing. It constitutes itself more fundamentally through the relevant actors conducting themselves on a regularised basis and in a manner they regard as obligatory (even if large elements are characterised by courts as non-justiciable).

It is my view that the major failing of Treaty principles has not been that in the articulation they have been racially divisive as the sponsor of the Treaty Principles Deletion Bill insisted. Rather the problem has been that their implementation has not been thorough. Māori lost an important opportunity when their representatives rejected inclusion of a Treaty principles clause in the Bill of Rights Act 1990 (BORA). This would have given those principles a clear application throughout the public sector. As it was, in the wake of the Maori Council cases, numerous governmental bodies audited their performance in terms of the principles articulated by the courts and embodied in the Crown Principles for Action (1989, revised 2000). ${ }^{73}$ As a result Treaty-compliant practices or at least Treaty-audit mechanisms began to permeate the administrative practices of the public sector. This was less a result of the actual court decisions, which affected the state enterprises segment of the public sector, than the outcome of the spectre that the cases seemed to be raising and which the government acknowledged in articulating its Principles for Crown Action. There was a belief that an

72 This echoes the approach of Matthew SR Palmer "What is New Zealand's Constitution and Who Interprets It? Constitutional Realism and the Important of Public Office-holders" (2006) 17 PLR 133 and "Constitutional Realism about Constitutional Protection: Indigenous Rights under a Judicialized and a Politicized Constitution" (2007) 29 Dal LJ 1.

73 Geoffrey Palmer "The Treaty of Waitangi - principles for Crown action" (1989) 19 VUWLR 335. As Acting Prime Minister Palmer announced the Principles for Crown Action by which government would act when dealing with issues arising from the Treaty of Waitangi. 
intense process of law-formation was about to occur, led by the courts, and that the public sector needed to be ready. There was a sense that this responsiveness to Treaty principles was likely to become a legal necessity, but there was also a perception of the constitutional tenor of the Maori Council cases. The cases were put in a constitutional light and, so located, became the foundation for an adjustment of institutional behaviour. Again, the constitutional actors moved without being required to do so by the courts. It was a perceptual matter that was acted upon and in so doing carried constitutional consequence. In that sense the Court of Appeal's judgments were at least partially (if not wholly) responsible for awakening those soft law practices and revision of institutional process.

The Maori Council cases were as remarkable, then, for the widespread revision of institutional practices that they initiated and which the Crown Principles anointed, as in their actual holdings. Again, it was a case of constitutional actors perceiving an obligation and adjusting their behaviour in the light of it.

As it was, that spectre of active judicial formation of a comprehensive Treaty jurisprudence did not materialise. The radical extension of Treaty principles by the courts that some were auguring in the Cooke years ${ }^{74}$ did not materialise. Still, the incomplete reach of Treaty principles meant that many public bodies that had responded positively to them remained in the dark as to whether this was obliged at law. A Treaty principles clause in the BORA would have confirmed their sense that the constitutional renewal spoken of by the Court of Appeal was also required at law. The reason why the courts did not extend the reach of Treaty principles mainly lay in the nature of the cases coming before them which is, of course, how judges develop and amplify the common law. Most of the litigation arose in areas that did not invite the courts to embark upon such activity even had they been minded to do so, notably those identified earlier (being the historic claims and fisheries settlement processes).

As I have been stressing, the profile of the Māori jurisprudence in the 1990s and 2000s has been mostly conservative. It has largely occurred in particular self-contained areas where its capacity to infiltrate the wider sphere has been limited. For the most part it has been happening well below the public sightline. And as this has happened it has become not only an inherently conservative but also an embedded jurisprudence. Given what it has accomplished and continues to achieve one wonders why on earth anyone would want to discontinue it or at least sever one of its important limbs?

There has been one exception, if that it be, to the conservative pattern of the court-led jurisprudence and that was Ngati Apa $v$ Attorney General, ${ }^{75}$ the foreshore and seabed case. However, this was not a Treaty principles case but one regarding the statutory jurisdiction of the

74 Philip Joseph "Constitutional Review Now" [1998] NZ Law Rev 85.

75 Ngati Apa and others v Attorney General [2003] 3 NZLR 643 (CA). 
Maori Land Court and common-law aboriginal title. The reaction that it sparked confirmed the extent to which the jurisprudence of Māori affairs had become a conservative if not complacent legalism inside several "pots" that bubbled away below the public sightline: historic and fisheries settlements, the RMA litigation and ongoing operation of Te Ture Whenua Maori Act 1993.

The foreshore and seabed experience was not a happy one but one of its lessons entailed the realisation that the jurisprudence had become settled and was operating on the basis of a known set of rights, advancing and consolidating those. The Ngati Apa judgments suggested there might be a set of new Māori rights previously unrecognised at law (although awareness of the possibility of unextinguished rights around the coastline had been in circulation for years). ${ }^{76}$ The case came at a time when certainly the executive branch believed that all those rights had been substantially provided for and were being accommodated inside those pots. The new rights - or rather the spectre of new rights - rocked what was until then a complacent jurisprudence. The displacement caused by the foreshore and seabed controversy underlined the character of the Māori jurisprudence, taking it back to a more turbulent time when the key rights were more inchoate and hence uncontained.

What would happen, then, if Parliament were to delete the recognition of Treaty principles from the range of statutes in which they are included? Since those principles are a big segment of a jurisprudence that has been both conservative and embedded, it is my belief that the courts would feel obliged to fill the vacuum their removal would leave. Instead of a legalism that is contained and bounded by the words and compass of a statutory regime I believe courts would resort to commonlaw devices to put something resembling the old principles in place. Certainly the foundation is there: the courts have been low-profile in this sphere precisely because the partners are getting on with the business of conducting their political relations mostly below the public sightline in specialised fora with their own legalism and kawa (Māori protocol). At present those relations may be happening in a less than perfect manner but not to an extent that the courts have charged in and generated a radical Treaty jurisprudence or forced the hand and pace of claims resolution processes. All that might change if the statutory basis for Treaty principles were taken away.

For instance, remove Treaty principles and the courts might then invoke the notion of Crown fiduciary duty to its aboriginal peoples. This is a common-law concept that New Zealand courts so far have eschewed applying to Crown-tribe relations despite suggestive dicta from the Court of Appeal in the Maori Council cases. It is now well-developed in Canadian jurisprudence. ${ }^{77}$ In New

76 The key articles were PG McHugh "Aboriginal Title in New Zealand Courts" (1984) 2 Cant LR 235; "The Legal Status of Maori Fishing Rights in Tidal Water" (1984) 14 VUWLR 247; and Richard Boast "In Re Ninety Mile Beach Revisited: The Native Land Court and the Foreshore in New Zealand Legal History" (1993) 23 VUWLR 145. In 1998 I wrote a commissioned paper for the (New Zealand) Ministry of Justice suggesting that there remained unextinguished customary rights in New Zealand, the coastline included.

77 See Frame, ibid. I have argued since 1986 that New Zealand courts could apply this doctrine, but during the 1990 s it became apparent that they were avoiding (as opposed to rejecting) it. Professor Frame misrepresents my inquiry into why this avoidance occurred during the 1990s, which is (of course) 
Zealand the doctrine's key predicate of an asymmetrical constitutional relation between Crown and particular tribal nations is even more applicable in that there is no overriding constitutional protection of Māori rights matching section 35 of The Canada Act. They might well revisit that reluctance and use it as a basis for doctrinal development. Similarly some of the tools of administrative law such as legitimate expectation and mandatory relevant considerations might also be used more imaginatively to fill the gaps arising from the disappearance. Of course, one cannot speculate where or how that would happen, but the point is that the removal of a conservative and embedded jurisprudence would invite the courts to build their own version. Thus the statutory deletion of Treaty principles would invite rather than eliminate the very judicial "activism" that the Bill's author so evidently and so strongly dislikes. It is a political gesture of the most bizarre and uninformed type. It would set government and court in false contest.

In thinking of that potential disjuncture between constitutional law and fact there are these these prescient words of Sir John Salmond: ${ }^{78}$

\footnotetext{
Although the constitution de jure and the constitution de facto are not necessarily the same, they nevertheless tend towards coincidence. Constitutional law and practice react upon each other, each striving to assimilate the other to itself. The objective facts of state organisation tend to mould legal theory into conformity with themselves. They seek expression and recognition through legislation, or through the law-creating functions of the courts. Conversely, the accepted legal theory endeavours to realise itself in the facts. The law, although it necessarily involves a pre-existing constitution, may nevertheless react upon and influence the constitution from which it springs. ... The will of the body politic, as expressed through the legislature and the courts, will commonly realise itself in constitutional fact no less than in constitutional theory.
}

Sir John Salmond's suggestion that somehow constitutional law will converge with constitutional fact seems applicable here. The conservative jurisprudence of Māori affairs has not only become embedded but it is an embedding one, spreading deep roots through our institutions of governance. It has entailed the adoption and maintenance of processes in the practices of the public sector that in the past two decades have become longstanding, habituated and habitual. In that sense the constitutional and institutional adjustments that the Maori Council cases initiated have become irreversible. At present our constitutional law largely meshes with those facts. But undo that law and somehow, as Salmond suggested, a reconvergence will occur. Judges will see the onus as theirs

essentially an historical question (see McHugh, ibid, especially 94.). He claims, wrongly, that I have argued the doctrine has been rejected in New Zealand courts, so confounding an historical inquiry with a legal conclusion (which I have never offered). The (historical) observation that the courts have not so far adopted the doctrine is not a legal conclusion that it has been authoritatively rejected. On the difference between an historical account and a legal conclusion see McHugh Aboriginal Societies and the Common Law, above $\mathrm{n}$ $3,16-23$.

78 JW Salmond Jurisprudence, or the Theory of the Law (Stevens and Haynes, London, 1902) 205. 
through "the law-creating functions of the courts". They will feel pressed to bring constitutional law into a sort of harmony with constitutional practice, acting on the imperative recognised by Salmond.

As the Treaty Principles Deletion Bill has died in the water that judicial activism is no more than a projection of an unlikely situation. But it has given the opportunity to see the Māori jurisprudence for what it has become: highly tribalised, conservative, embedded, consolidating, and a constitutional phenomenon primarily driven by the actors themselves with the courts, for all the flamboyance with which Māori have recourse to them and seek to deploy their mana, playing cautious touch judge. The jurisprudence is not founded on race, but on recognition and maintenance of a pattern of political relations with tribal polities (whose stock has been revitalised by the historic claims processes). This jurisprudence has ballooned in the twenty-five years since I entered the field at a time when conception of aboriginal rights was the discourse primarily of a group of academics whose mission was to persuade the courts to take the lead and articulate a set of rights. Whether because of, or, more likely, despite that encouragement, the courts were instrumental in bringing aboriginal nations into the rights-place. In North America and Australasia the courts instigated the new rights-era for tribes. In New Zealand the judgments of the Court of Appeal presided by Sir Robin Cooke in the Maori Council cases were instrumental in ensuring and enhancing the historic claims processes. Yet those cases had wider-ranging consequences, the perception of an "activist" court prompting Crown acknowledgment of Māori rights in other spheres - such as fisheries and bureaucratic practices - where strictly there was then no legal compulsion. In accomplishing this change, the Maori Council cases are undoubted landmarks in New Zealand constitutional history embodying the intellectual leadership of Sir Robin Cooke.

Even though the jurisprudence that followed the Maori Council cases has been conservative in tone that very quality is not necessarily a vice. Living with rights has brought new challenges for Māori within the legitimating compass of a constitutional system that now acknowledges their presence as a series of whakapapa-based polities. Rights are not a result. Living with them, and what they secure, represents an ongoing process for the rights-holders more problematic than the simple black and white scenario of denial. The nature of those rights, and the realisation of their potential, is inherently piecemeal. Some see their scope as inadequate and regard the process of resolution as deeply flawed. For iwi and hapū, as the present activity of the Law Commission signifies, the tasks of rights-management (governance) and -integration are not easy, whether it be constructing the mode for those tasks (pre-settlement) or actually driving them (post-settlement or in contexts such as RMA participation). This rights-centred activity has become the new reality for Māori groups, and if one is to talk of a Māori jurisprudence or the legalism spawned by Treaty principles it should be in terms of these contemporary challenges before iwi and hapū. These, after all, are human formations united by kin in which a wide range of views and dispositions will naturally occur.

Whilst deeply felt by Māori and intensely debated amongst themselves, those processes of tribal rights-management and -integration have largely been hidden from Pākehā eyes. The challenge for the New Zealand constitutional system is to facilitate that activity, not to obliterate it. Instead, 
certain politicians have depicted a highly variegated and tribalised legalism as a simple matter of race-based preference and as a gravy train in which Treaty principles are to blame. Race has nothing to do with the complex set of rights held by Māori other than in the proscription of discrimination on grounds of race (or, for that matter, sex, religion, age or sexual orientation) affecting all New Zealanders. Race is a simplistic and Eurocentric way of seeing the world. In describing Māori issues and experience in racialised terms politicians are saying that world is the way they see and deem it to be. It is an act of arrogance. It is mischievous, reductionist and oblivious to the constitutional basis of Crown relations with the tribes. It is also old hat; those relations are located inside a conservative juridical sphere that has long since moved beyond facile racist characterisation. 